\title{
Membrane potential based accumulation of antioxidants into mitochondria: implications in neurodegenerative diseases
}

\author{
Deepali jat \\ Doctor Hari Singh Gour University Sagar, M.P.- 470003
}

\begin{abstract}
Lipophilic phosphonium cations were used to investigate mitochondrial biology by delivering them in mitochondria in the late 1960s. Since then, these molecules have become useful for exploring mitochondrial bioenergetics and free radical biology. The cations moves rapidly and carry antioxidants to mitochondria the process is entirely based on membrane potential $(\Delta \Psi)$. Here the investigation is carried out to synthesize and delivered antioxidants to brain mitochondria using lipophilic triphenylphosphonium cation.
\end{abstract}

Key words: lipophilic phosphonium cations, membrane potential, antioxidants.

\section{Introduction}

Mitochondria bioenergetics play a central role in a cell's survival. Hence it is not surprising that disintegrated mitochondrial functioning can cause variety of diseases such as neurodegenerative disorders and disorders associated with mitochondrial DNA mutations [1,2] . To this context membrane potential based accumulation of an antioxidant may proved to be potential therapies in ameliorating defective mitochondrial functioning in neuronal mitochondria isolated from mice brain. To overcome problems associated with mitochondrial dysfunctioning, drug have been synthesized attaching antioxidant gallic acid to lipophilic cation. The positive charge of these lipophilic cations enables antioxidants to permeate lipid bilayers easily and to accumulate several hundredfold within mitochondria, because of the large membrane potential $(-150$ to -170 $\mathrm{mV}$, negative inside[3,4]. The plasma membrane potential ( -30 to $-60 \mathrm{mV}$, negative inside) also drives the accumulation of these molecules from the extracellular fluid into isolated cells, from where they are concentrated further within mitochondria, with $>90 \%$ of intracellular lipophilic cations being present in mitochondria [5,6]. Delivering molecules selectively within mitochondria may prove to be a useful tool for understanding mitochondrial bioenergetics in apoptotic events as well as therapeutic concerns of these molecules against the challenges occur due to oxidative stress.

\subsection{Mitochondria targeted derivative of antioxidant}

\section{Materials And Methods}

TPP bromide was from Sigma. MitoGA, were prepared as described [7,17,18]. Reactions were carried out under a nitrogen atmosphere. To synthesize targeted derivative a solution of bromo-antioxidant (Gallic acid; $2 \mathrm{gm}, 1.06 \mathrm{mmol}$ ) was refluxed and evaporated the volatiles under vaccum below $100^{\circ} \mathrm{C}$. The compound obtained was hygroscopic, dissolved in methanol and precipitated after adding $\mathrm{n}$-hexane. Filtered precipitate was again dissolved in methanol containing triphenylphosphine $(1.5 \mathrm{gm}, 0.098 \mathrm{mmol})$. After refluxing the solution, evaporated the volatiles under vaccum to obtain targeted derivative of gallic acid.

\subsection{Animals and Administration Protocols}

Female Swiss-albino mice ( $8-10$ weeks old; $\approx 20-30 \mathrm{~g}$ ) were supplied by the Department of Laboratory Animal and veterinary Sciences, Mhow, and were maintained at $22-23^{\circ} \mathrm{C}$ on a $12-\mathrm{h} \mathrm{light} / 12-\mathrm{h}$ dark cycle and had free access to drinking water and standard chow. All experiments were approved by the animal ethics committee. Weight, appearance, and behavior were monitored continually to gauge gross effects of the administered compounds. Mice were decapitated and whole brain was removed quickly, cleaned and washed twice in ice-cold phosphate buffered saline ( $\mathrm{pH} 7.4)$ and homogenized in $10 \%(\mathrm{w} / \mathrm{v})$ ice-cold buffer, $(\mathrm{pH} 7.4)$, containing sucrose $(250 \mu \mathrm{M})$, EDTA $(1 \mu \mathrm{M})$ and Tris-Cl $(10 \mu \mathrm{M})$ with the help of a motor driven teflon homogenizer. Homogenate was stored at $-20^{\circ} \mathrm{C}$ and used for mitochondrial isolation.

\subsection{Preparation of culture media}

Efficacy of mitochondrially targeted antioxidants was tested after delivering three of its targeted and untargeted derivative to mitochondria in separate studies. Antioxidative activity of gallic acid and its targeted derivatives (concentration;100-500 $\mu \mathrm{M}$ ) were observed in isolated mitochondria (incubation medium containing; $2 \mathrm{mM}$ Phosphoric acid (pH 7.4), $15 \mathrm{mM}$ Tris- $\mathrm{Cl}$ (pH 7.4) and $120 \mathrm{mM} \mathrm{KCl}$ at $30^{\circ} \mathrm{C}$ for three to four hours against neurotoxicants such as, $\mathrm{FeSO}_{4}(30 \mu \mathrm{M})+$ Ascorbic acid $(500 \mu \mathrm{M})$. After the completion of 
experiment, $10 \mu \mathrm{m}$ ortho-toluidine was added to the incubation medium to terminate the reaction. Mitochondria incubated in incubation medium were centrifuged at $5000 \mathrm{rpm}$ for 10 minutes after adding $1 \mathrm{mM}$ EDTA and the supernatent was assayed for LPO, PC and GSH contents.

\subsection{Biochemical Estimations}

Definite volume of supernatent (in vitro) and mitochondrial fraction (in vivo) were mixed in $0.05 \mathrm{M}$ phosphate buffer for lipid peroxidation (LPO) assay, in $0.1 \mathrm{M}$ metaphosphoric acid containing $2 \mathrm{mM}$ EDTA for reduced glutathione assay and in $100 \mathrm{mM}$ phosphate buffer $(\mathrm{pH}$ 7.4) containing $0.1 \%$ digitonin for protein carbonyl assay.

\subsubsection{Assay for lipid peroxidation}

LPO was determined following the method of Ohkawa et al (1979)[8]. The thiobarbituric acid reactive substances (TBARS) test is most regularly used method for the estimation of peroxidation of biological membranes and fatty acids. The method is based on the principle that the peroxidation products of membrane lipids, malondialdehyde (MDA) and 4- hydroxynonenal, when heated with thiobarbituric acid (TBA) in acidic medium, form pink colored complexes which is having an absorption maximum at $532 \mathrm{~nm}$.

\subsubsection{Assay for protein carbonyl (PC) content}

Protein carbonyl content was determined following the method of Levine et al. (1990) [9]. In this method amino acid oxidized via the Fenton reaction of $\mathrm{Fe}^{2+}$ and $\mathrm{H}_{2} \mathrm{O}_{2}$ generated by mixed function oxidases. The $\mathrm{Fe}^{2+}$ binds to an enzyme at a metal binding site and reacts with the $\mathrm{H}_{2} \mathrm{O}_{2}$ to yield a ROS which immediately attacks the side chain of amino acid residues in a site specific manner at the metal binding sites of the proteins.

\subsubsection{Assay for reduced glutathione (GSH)}

Reduced glutathione was measured in the samples following the method of Jollow et al. (1974) [10] involving the spectrophotometric assessment of the formation of 5-thio-2-nitrobenzoate from 5,5'-dithio-bis-2 (nitro-benzoate) in the presence of NADPH and glutathione reductase.

\subsection{4 protein assay}

Lowry method was used for protein assay in mitochondrial fraction[11].

\section{Results}

3.1 Neuroprotective effect of mitochondrially targeted gallic acid (mtGA) on mice brain mitochondria : in vitro

\subsubsection{Lipid peroxidation}

In the groups receiving toxicants like $\mathrm{Fe}^{2+}$ - ascorbate the values of peroxidation products formed increased significantly $(\mathrm{P}<0.05)$ as compared to their respective control values. On the other hand gallic acid $(\mathrm{GA})$ and its mitochondrially targeted derivative $(\mathrm{mtGA})$ showed significantly $(\mathrm{P}<0.05)$ decreased LPO activity against toxicants such as $\mathrm{Fe}^{2+}$-ascorbate. Comparisons of peroxides scavenging ability between GA and mtGA are shown in fig. 10. The TBARS assay showed significantly $(\mathrm{P}<0.05)$ higher radical scavenging activity of GA and $\mathrm{mtGA}$. The free radical scavenging ability of $\mathrm{mtGA}$ was stronger compared to GA. As shown in TABLE 10 LPO was noted $0.070 \pm 0.007 \mathrm{~nm} / \mathrm{MDA} / \mathrm{mg}$ protein in control, $0.135 \pm 0.06 \mathrm{~nm} / \mathrm{MDA} / \mathrm{mg}$ protein in $\mathrm{Fe}^{2+}$ ascorbate, $0.082 \pm .05$ in GA and $0.072 \pm 0.006$ in $\mathrm{mtGA}$ treated group.

\subsubsection{Protein carbonyl content}

Significant $(\mathrm{P}<0.05)$ increase in oxidatively altered mitochondrial proteins was observed after incubating mitochondria with three toxicants $\left(\mathrm{Fe}^{2+}\right.$-ascorbate) . The amount of oxidatively modified proteins were noted $80.25 \pm 0.032 \mathrm{~nm} / \mathrm{mg}$ protein $\left(\mathrm{Fe}^{2+}\right.$-ascorbate) in comparison to their control values. However, protein oxidation was significantly $(\mathrm{P}<0.05)$ decreased gradually with the increase in the concentrations of antioxidants, GA and mtGA (100 to $500 \mu \mathrm{M})$. The decrease in protein oxidation was noted $62.20 \pm 0.75$ in GA and 55.90 \pm 0.053 in mtGA, against their respective toxicant as shown in TABLE 11 and fig. 11. The carbonyl content scavenging capacity of mtGA was stronger compared with the GA .

\subsubsection{Glutathione status (GSH) in mitochondria}

Significant $(\mathrm{P}<0.05)$ loss of GSH content have been found in brain mitochondria exposed to GSHdepleting agents $\left(\mathrm{Fe}^{2+}\right.$-ascorbate), GSH depeletion caused striking degeneration of brain mitochondria. However, incubation of mitochondria with gallic acid and mtGA increased glutathione in isolated mitochondria. The relative increase was smaller with GA incubated group compared with its targeted derivative (mtGA) treated group. As shown in fig. $12 \mathrm{GSH}$ level was found to $33.02 \pm 0.07$ in control, $18.20 \pm 0.06 \mathrm{mg} / \mathrm{g}$ wet wt. in 
$\mathrm{Fe}^{2+}$-ascorbate, $28.90 \pm 0.05 \mathrm{mg} / \mathrm{g}$ wet wt. in $\mathrm{GA}$ and $32.00 \pm 0.04 \mathrm{mg} / \mathrm{g}$ wet wt. in $\mathrm{mtGA}$ (TABLE 12). The results displayed marked elevation in glutathione content in antioxidants treated group. A significant $(\mathrm{P}<0.05)$ elevation was noted in mtGA treated group than GA treated group. Results suggest strongest antioxidant activity of gallic acid against toxicant in mitochondria.

Table : 10

Lipid peroxidation (nmoles MDA mg-1 protein) in brain mitochondria of swiss albino mice after incubation with $\mathrm{Fe}^{2+}(30 \mu \mathrm{M})+$ ascorbate $(500 \mu \mathrm{M})$ and mitochondrially targeted and untargeted derivative of gallic acid $(100-500 \mu \mathrm{M})$.

\begin{tabular}{|l|c|c|c|c|c|}
\hline \multirow{2}{*}{ Treatments } & \multicolumn{5}{|c|}{ Mitochondrially Targeted Antioxidant (Concentration in $\mu \mathrm{M})$} \\
\cline { 2 - 6 } & 100 & 200 & 300 & 400 & 500 \\
\hline Control & $0.07 \pm .007$ & $0.07 \pm .007$ & $0.07 \pm .007$ & $0.07 \pm .007$ & $0.07 \pm .007$ \\
\hline $\mathrm{Fe}^{2+}$-ascorbate & $0.13 \pm 0.06^{*}$ & $0.13 \pm 0.06^{*}$ & $0.13 \pm 0.06^{*}$ & $0.13 \pm 0.06^{*}$ & $0.13 \pm 0.06^{*}$ \\
\hline $\begin{array}{l}\mathrm{Fe}^{2+} \text {-ascorbate + } \\
\text { Gallic acid }\end{array}$ & $0.12 \pm 0.04 \#$ & $0.10 \pm 0.02 \#$ & $0.09 \pm 0.03 \#$ & $0.09 \pm 0.03 \#$ & $0.082 \pm 0.05 \#$ \\
\hline $\begin{array}{l}\mathrm{Fe}^{2+} \text {-ascorbate + } \\
\mathrm{mtGA}\end{array}$ & $0.09 \pm 0.007 \#$ & $0.08 \pm 0.009 \#$ & $0.08 \pm 0.005 \#$ & $0.07 \pm 0.006 \#$ & $0.072 \pm 0.006 \#$ \\
\hline
\end{tabular}

Data expressed in terms of mean \pm S.E. $* \mathrm{P}<0.05$, compared to control. \# $\mathrm{P}<0.05$, compared to $\mathrm{Fe}^{2+}$-ascorbate induced mitochondria.

Table : 11

Protein carbonyl (PC) concentration (nmoles $\mathrm{mg}^{-1}$ protein) in brain mitochondria of swiss albino mice after incubation with $\mathrm{Fe}^{2+}(30 \mu \mathrm{M})+$ ascorbate $(500 \mu \mathrm{M})$ and mitochondrially targeted and untargeted derivative of gallic acid $(100-500 \mu \mathrm{M})$.

\begin{tabular}{|l|c|c|c|c|c|}
\hline \multirow{2}{*}{ Treatments } & \multicolumn{5}{|c|}{ Mitochondrially Targeted Antioxidant (Concentration in $\mu \mathrm{M})$} \\
\cline { 2 - 6 } & 100 & 200 & 300 & 400 & 500 \\
\hline Control & $55.04 \pm 0.17$ & $55.04 \pm 0.17$ & $55.04 \pm 0.17$ & $55.04 \pm 0.17$ & $55.04 \pm 0.17$ \\
\hline $\mathrm{Fe}^{2+}$-ascorbate & $80.25 \pm 0.32^{*}$ & $80.25 \pm 0.32^{*}$ & $80.25 \pm 0.32^{*}$ & $80.25 \pm 0.32^{*}$ & $80.25 \pm 0.32^{*}$ \\
\hline $\begin{array}{l}\mathrm{Fe}^{2+} \text {-ascorbate + } \\
\text { Gallic acid }\end{array}$ & $72.20 \pm 0.99 \#$ & $72.00 \pm 0.097 \#$ & $70.49 \pm 0.087 \#$ & $65.25 \pm 0.086 \#$ & $62.20 \pm 0.75 \#$ \\
\hline $\begin{array}{l}\mathrm{Fe}^{2+} \text {-ascorbate + } \\
\text { Gallic acid }\end{array}$ & $69.02 \pm 0.42 \#$ & $62.00 \pm 0.22 \#$ & $59.231 \pm 0.91 \#$ & $58.00 \pm 0.082 \#$ & $55.00 \pm 0.053 \#$ \\
\hline
\end{tabular}

Data expressed in terms of mean \pm S.E. $* \mathrm{P}<0.05$, compared to control. \# $\mathrm{P}<0.05$, compared to $\mathrm{Fe}^{2+}$-ascorbate induced mitochondria.

Table : 12

Reduced glutathione content $\left(\mathrm{mg} \mathrm{gm}^{-1}\right.$ wet wt.) in brain mitochondria of swiss albino mice after incubation with $\mathrm{Fe}^{2+}(30 \mu \mathrm{M})+$ Ascorbate $(500 \mu \mathrm{M})$ and mitochondrially targeted derivative of gallic acid $(100-500 \mu \mathrm{M})$.

\begin{tabular}{|l|c|c|c|c|c|}
\hline \multirow{2}{*}{ Treatments } & \multicolumn{5}{|c|}{ Mitochondrially Targeted Antioxidant (Concentration in $\mu \mathrm{M})$} \\
\cline { 2 - 6 } & 100 & 200 & 300 & 400 & 500 \\
\hline Control & $33.02 \pm 0.07$ & $33.02 \pm 0.07$ & $33.02 \pm 0.07$ & $33.02 \pm 0.07$ & $33.02 \pm 0.07$ \\
\hline $\mathrm{Fe}^{2+}$-ascorbate & $18.20 \pm 0.06^{*}$ & $18.20 \pm 0.06^{*}$ & $18.20 \pm 0.06^{*}$ & $18.20 \pm 0.06^{*}$ & $18.20 \pm 0.06^{*}$ \\
\hline $\begin{array}{l}\mathrm{Fe}^{2+} \text {-ascorbate }+ \\
\text { Gallic acid }\end{array}$ & $24.52 \pm 0.02 \#$ & $24.90 \pm 0.03 \#$ & $26.01 \pm 0.03 \#$ & $27.72 \pm 0.04 \#$ & $28.90 \pm 0.05 \#$ \\
\hline $\begin{array}{l}\mathrm{Fe}^{2+} \text {-ascorbate }+ \\
\mathrm{mtGA}\end{array}$ & $25.00 \pm 0.06 \#$ & $29.02 \pm 0.06 \#$ & $29.90 \pm 0.05 \#$ & $30.01 \pm 0.05 \#$ & $32.00 \pm 0.04 \#$ \\
\hline
\end{tabular}

Data expressed in terms of mean \pm S.E. $* \mathrm{P}<0.05$, compared to control. \# $\mathrm{P}<0.05$, compared to $\mathrm{Fe}^{2+}$-ascorbate induced mitochondria. 


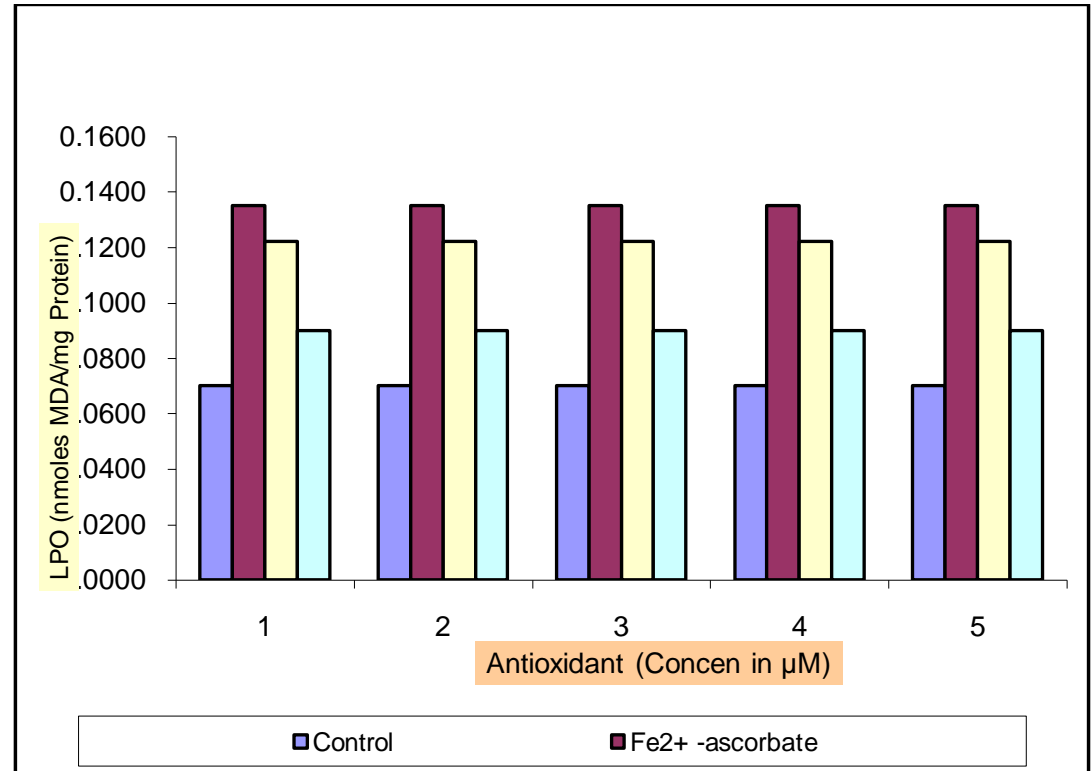

FIGURE 10

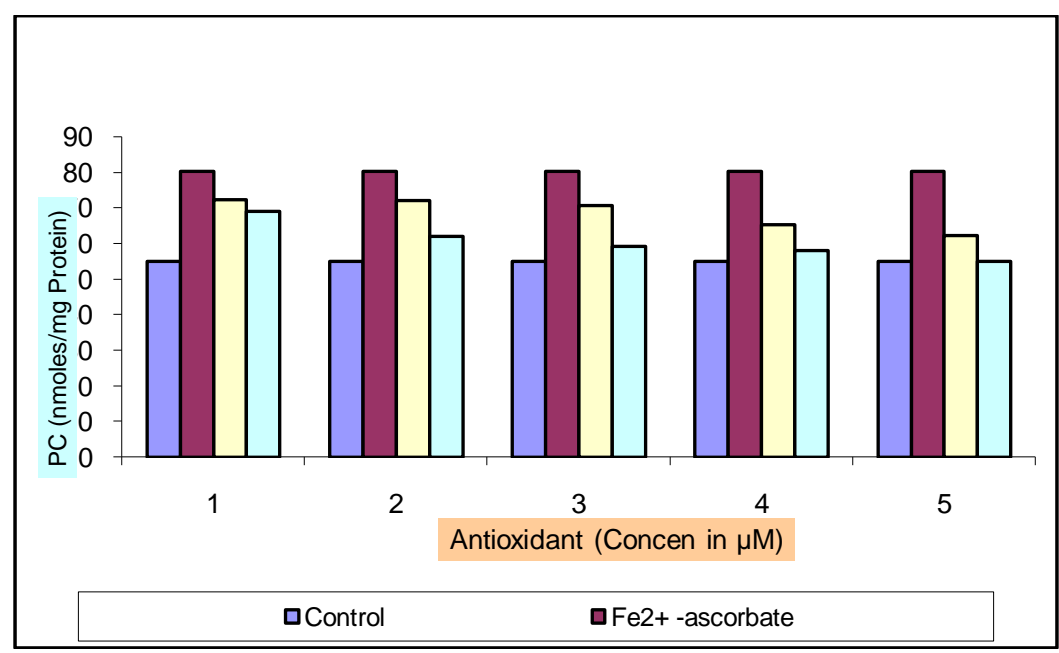

FIGURE 11

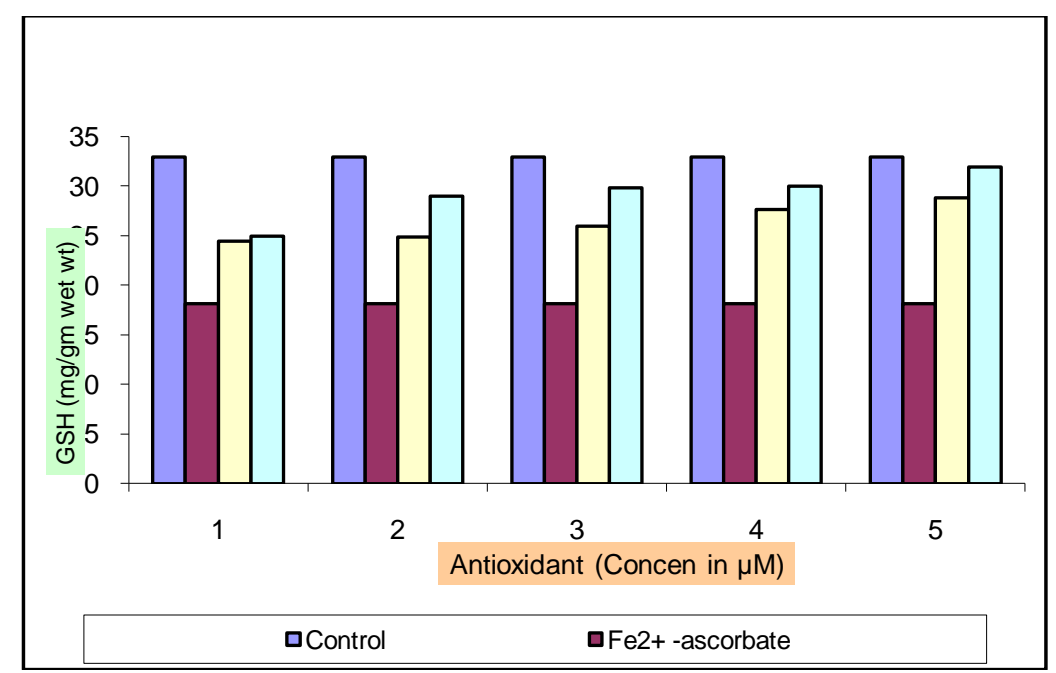

FIGURE 12 


\section{Conclusion}

In this study it has shown that mitochondria-targeted compounds containing lipophilic triphenylphosphonium cation accumulate within brain mitochondria in vitro. Experiments with the mitochondria-targeted drugs suggested that these compounds were predominantly incorporated into mitochondria.This approach enables a range of small molecules to be targeted to mitochondria and extends and complements earlier approaches designed to target DNA and related molecules to mitochondria[12,13].Lipophilic cations are toxic at high concentrations because their excessive uptake by mitochondria disrupts ATP synthesis. Even so, substantial doses of TPMP and MitoVit E were well tolerated by delivery from drinking water (30 and $60 \mathrm{mg} / \mathrm{kg} / \mathrm{day}$, respectively). The maximum tolerated acute doses by i.v. injection were 6, 10, and $20 \mathrm{mg} / \mathrm{kg}$ for TPMP, MitoVit E, and MitoQ, respectively. Interestingly, the maximum tolerated acute doses were broadly similar, despite the quite different side chains and hydrophobicities of the three compounds[14]. mitochondria-targeted antioxidant concentrations of $1-2.5 \mu \mathrm{M}$ were effective in preventing oxidative damage to isolated mitochondria $[15,16,17]$. As these compounds will be accumulated further into cells, similar protective effects should be found by incubating cells with lower concentrations, and consistent with this $500 \mathrm{nM}$ to $1 \mu \mathrm{M}$ concentrations of mitochondria-targeted antioxidants are protective in cultured cells[18,19]. To conclude, we have shown that mitochondria-targeted compounds can be delivered to the mice brain mitochondria. Mitochondria are a particularly important but neglected intracellular drug target because of their central position in energy and intermediate metabolism and their role in cell death[20,21]. This study provide new tools to develop novel compounds as potential therapies for diseases associated with mitochondrial bioenergetics and prove to be beneficial in exploring how mitochondrial damage contributes to neurodegenerative diseases.

\section{References}

[1]. S.Pitkanen ,B.H. Robinson (1996) J Clin Invest 98,1996,345-351, pmid:8755643.

[2]. D.C.Wallace (1999) Science 283,1999,1482-1488, pmid:10066162.

[3]. M.P.Murphy, Trends Biotechnol 15,1997,326-330, pmid:9263481..

[4]. E.A.Liberman ,V.P. Topali, L.M. Tsofina ,A. A. Jasaitis, V.P. Skulachev , Nature 222,1969,1076-1078, pmid:5787094.

[5]. R.H.Burdon, P.H.van Knippenberg , M.N.Berry ,A.M. Edwards, G.J. Barrit ,M.B. Grivell, Halls H J, Gannon B J, Friend D S, in Laboratory Techniques in Biochemistry and Molecular Biology, eds Burdon R H, van Knippenberg P H,Elsevier, Amsterdam, 21,1991, 386-390.

[6]. Burns R J, Murphy M P, Arch Biochem Biophys 339,1997,33-39, pmid:9056230.

[7]. T.K.Lin , G. Hughes ,A. Muratovska,F.H. Blaikie, P.S.Brookes ,V. Darley-Usmar ,R.A.J.Smith ,M. P.Murphy (2002) J Biol Chem 277,2002,17048-17056, pmid:11861642.

[8]. H.Ohkawa ,N. Ohishi, K.Yoge , Assay for lipid peroxides in animal tissues by thiobarbituric acid reaction, Annal Biochem 95, 1979, 351-358.

[9]. R.L.Levine ,D. Garland ,C.N. Oliver, A. Amici ,J. Climent, A.G.Lenz ,B.W. Ahn ,S. Shaltiel ,E.R. Stadtman , Determination of carbonyl content in oxidatively modified mice Methods in Enzymology $186,1990,464-478$.

[10]. D.J.Jollow ,J.R. Mitchell ,N. Zampaglione ,J.R. Gillete (1974) Bromobenzene induced liver necrosis, protective role of glutathione and evidence for 3, 4-bromobenzene oxide as the toxic metabolite, Pharmacology 11,1974, 151-169

[11]. O.H.Lowry ,N.J. Rosenbrough ,A.L. Farr ,R.J. Kandal , (1951) Protein measurement with the folin phenol reagent, J Biol Chem 193,1951,265-275.

[12]. P.E.A.Seibel ,J. Trappe, G. Villani ,T. Klopstock ,S. Papa ,H. Reichmann, Nucleic Acids Res 23,1995,10-17, pmid:7870573.

[13]. D.Vestweber,G.Schatz,Nature 338,1989,170-172, pmid:2918937.

[14]. R.A.J.Smith,M.P.Carolyn,M.G.Alison,M.P.Murphy,Delivery of bioactive molecules to mitochondria in vivo, pnas.org, 100(9), 2002,5407-5412.

[15]. G.F.Kelso ,C.M. Porteous, C.V.Coulter, G.Hughes ,W.K. Porteous,E.C. Ledgerwood ,R.A.J. Smith ,M.P. Murphy ,J Biol Chem 276,2001,4588-4596, pmid:11092892.

[16]. R.A.J.Smith ,C.M. Porteous ,C.V. Coulter ,M.P. Murphy, Eur J Biochem 263,1999,709-716, pmid:10469134

[17]. K.S.Echtay, M.P. Murphy ,R.A.J.Smith ,D.A.Talbot,M.D.Brand ,J Biol Chem 277,2002,47129-47135, pmid:12372827.

[18]. P.M. Hwang ,F. Bunz ,J.Yu ,C. Rago ,T.A. Chan, M.P.Murphy ,G.F. Kelso ,R.A.J. Smith , K.W.Kinzler ,B. Vogelstein , Nat Med 7,2001,1111-1117, pmid:11590433

[19]. G.F. Kelso ,C.M. Porteous ,G. Hughes ,E.C. Ledgerwood ,A.M. Gane ,R.A.J. Smith ,M.P. Murphy , Ann NY Acad Sci 959,2002,263-274, pmid:11976201.

[20]. M.P. Murphy ,R.A.J. Smith, Adv Drug Delivery Rev 41,2000,235-250, pmid:10699318.

[21]. E.A. Schon, Trends Biochem Sci, 25,2000,555-560

[22]. Murphy M P, Trends Biotechnol 15,1997,326-330, pmid:9263481.

[23]. E.A.Liberman, V.P.Topali ,L.M.Tsofina, A.A. Jasaitis, V.P. Skulachev, Nature 222,1969,1076-1078, pmid:578094

[24]. R.H.Burdon ,P.H. van Knippenberg, M.N.Berry ,A.M. Edwards, G.J.Barrit ,M.B. Grivell , H.J.Halls ,B.J. Gannon ,D.S. Friend ,in Laboratory Techniques in Biochemistry and Molecular Biology, eds R.H. Burdon ,P.H. van Knippenberg (Elsevier, Amsterdam), 21,1991 pp 386-390.

[25]. R.J.Burns ,M.P. Murphy, Arch Biochem Biophys 339,1997,33-39, pmid:9056230. 